\title{
SEVENTH INTERNATIONAL GENETICAL CONGRESS
}

$\mathrm{T}$ HE chief qualifications demanded of those who undertake the organization of an international scientific congress in these days would seem to be an unwarrantable optimism and a complete disregard for current political events. At no time during the last two years has it ever been certain that the International Genetical Congress would meet, and now it is indeed surprising that it ever met.

It will be remembered that the Permanent International Committee appointed by the Sixth Congress at Ithaca in 1932 accepted the invitation of the Russian geneticists to hold the next Congress in Noscow in 1937. Difficulties arose, however, which made its postponement necessary. Late in 1937, the International Committec had reason to doubt that the Congress could be held in Moscow even in 1938, and found it necessary to seek invitations from other countries. The committec of the Genetical Society of Great Britain was informed that if we in this country were prepared to take over from the Russians, we should be rendering both the science and the International Committee a very great scrvice. Being assured that it was quite impossible for the Congress to meet in Moscow in 1938, the Genetical Society of Great Britain offered, in October 1937, to stage it in Great Britain in 1930. 'This offer was eagerly' accepted.

The committee of the Genctical Society formed itself into an organizing committee and decided that the Congress should meet in Edinburgh. F. A. E. Crew was appointed general secretary. Since N. I. Vavilov would have been the president of this Congress had it been held in Nloscow as was intended, and since we wished to indicate in the only manner available to us our great respect for him personally and our ardent desire for the active co-operation of the Russian geneticists in the affairs of the Congress, an invitation was sent to Yavilov asking him to continue in the presidency.

During. 1938 and the first half of 1939 , the programme of the Congress slowly took shape. At times the organizing committee had reason to think that its was a hopeless task; at others it was greatly encouraged by the eager co-operation extended to them by geneticists from all over the world. A programme built up of more than four hundred papers of quality was ultimately issued, whilst in London, Cambridge and Edinburgh preparations for the reception and entertainment. of some four hundred foreign guests were completed. Yet all the while doubt lurked in the minds of all of us. It was obvious to all that the day was not far distant when the flickering lamps of science would be dimmed, and the only question that concerned us was when this day would dawn. Should we be permitted to carry this Congress to its successful conclusion before we were required to leave the forges of knowledge and use tools that we had made, for unworthy and damnable purposes?

On the morning of August 23 there gathered for the first meeting of the Congress some six hundred geneticists drawn from fifty-five different countries. There could be no grander measure of the devotion that men of science give to the science they serve than this. They met in days heavy with anxiety, to consolidate the ground won by them and their colleagues during the last seven years. The Congress had met, but it lacked a president, for, a fortnight previously, information was received that no one from the U.S.S.R. would be attending. This was a wound which at the time seemed mortal, for it had been hoped that not only would Russia supply a president but also that fifty or more papers of outstanding quality would be presented. However, the vitality of the Congress was such that it survived, and for two days into its rooms none of the loud murmurings of the outside world entered. Looking back on those days, they now seem to have been a dream of what the world itself might be were all men reasonable.

It is true that according to the records there were Americans, French, Germans, Poles, and all the rest of a great geographical and political variety, yet these were divided by no barrier of language or of prejudice. They formed one harmonious whole, moved by a common purpose, to advance a science, to serve mankind, to cultivate a fellowship. But the murmurings outside grew in intensity, and towards the end of the second day the air became disturbed, and everyone began to remember his private responsibilities and duties. 'The first group to be seriously affected was the German delegation ( $3 \pm$ strong), which received advice that it would be desirable for them to think of returning home. 'This advice they resisted until it became quite certain that if they delayed longer they might encounter very serious difficulties in transportation; and so, most regretfully, and bearing with them the good wishes of their colleagues, they bade us farewell. At the same time, owing to mobilization of the Dutch army, the delegation from the Netherlands (17 strong) decided that it was desirable that they also should go From that moment onwards the citizens of Edinburgh looked upon the Congress as a trustworthy barometer. Hourly inquiries as to whether 
or not the Italians, the French and the Poles were still with us were received, and Edinburgh was comforted when it could be told that the French and the Poles were remaining with us, and that the Italians bad no intention of departing.

The programme, of course, was sadly crippled by this time, and for a while the organizing com. mittee considered the question as to whether or not, in the circumstances, it would not be advisable to bring the Congress to an abrupt end. However, the Congress itself decided that it should continue. There was little else that we could do save to indicate, by continuing, that science was worth serring even in days like these, and that it, of all things, offered the most enduring good to all mankind. But the Congress was shortened, for Sunday was made a working day. A brave gesture this, for it will be remembered that Edinburgh is the capital of Scotland. As things turned out, this decision was more than justified, for the meetings continued to be very well attended right to the end, and daily the congressists sat down to mighty repasts. Looking back upon the sessions from this short distance, it would seem that not one of them was remarkable for the announcement of any startling discovery, but that they were immensely useful in that, during them, differences were bridged and new lines of advance were traced.

The organizing committee received repeated expressions of congratulation for the way in which the Congress affairs were conducted. Those who congratulated us seemed to be unaware of the obvious fact that the quality of a Congress is determined not so much by its organization as by the personalities of its adherents. On this occasion we were more than ordinarily fortunate. From a great many countries there came strong delega. tions bringing contributions of knowledge, of friendliness, of charm. It was they who made this congress successful. To the Germans, to the French, to the Italians and to the Poles we are indeed indebted. They came at great personal inconvenience to our aid, and they have left behind them most happy memories. The coming of an American contingent, 130 strong, made the success of the Congress inevitable. But it is too much to expect that the welcome they received would com. pensate them for the distress that they endured when the Congress ended, for then they found themselves stranded in Great Britain with no immediate hope of return to their own. Already at least seven of them have been exposed to the gravest danger, for these were passengers on the Athenia and their fate at the moment of writing is not known. Some forty others have still to make the dangerous passage.

At the first business meeting of the Congress, F. A. E. Crew was elected to the presidency rendered vacant by $N$. I. Vavilov's absence. A Permanent International Committee, consisting of C. L. Huskins (Canada), O. Winge (Denmark), Boris Ephrussi (France), Von Wettstein (Germany), F. A. F. Crew (Great Britain), A. Ghigi (Italy), II. J. Sirks (Netherlands), Otto L. Mohr (Norway), G. Dahlberg (Sweden), A. Ernst (Switzerland), II. Demerec (United States of America), was appointed. This committee later elected F. A. E. Crew as its chairman.

At the second meeting of the Congress it was agreed that, in the circumstances, it was quite impossible at this particular time for the International Committee seriously to consider invita. tions and to decide as to the time and place of the next congress. It was intimated that invitations had been received from Italy and America. The International Committee was given authority to designate the time and place of the next congress at some later date.

Following a motion brought forward by the International Committee, the Congress decided that it should not be regarded as essential or necessary for future congresses to publish Proceed. ings. This decision was reached because it was recognized that, in the past, a number of invitations to meet therein had not been received from several countries on account of the expenses that are associated with the publication of the Proceedings. It was recognized that complcte autonomy must be given to the actual organizing committee of a particular congress as to whether or not Proceedings of that congress should be published.

The Congress considered the setting up of an international committee which would devise a scheme whereby animal and plant stocks of genetical importance could be maintained in times of emergency. The International Committee was asked to consider the matter and set up a committeo for this purpose.

During the course of the Congress a group meeting was arranged for the discussion on the statistical requirements of the student of genetics. At the end of this meeting the following resolutions were passed :

(1) That the teaching of statistics should be carried out in conjunction with the teaching of practical genctics.

(2) That elementary statistical methods, in particular tests of significance and their validity, should be included in the ordinary mathematical courses given at secondary schools.

(3) That the General Secretary of the Seventh International Congress of Genetics be requested to transmit copies of resolution 2 to any educational bodies which he considers may be able to assist in its fulfilment.

(4) That the genetical societies of countries 
represented at the Seventh International Congress of Genetics be requested to discuss the teaching of statistics in relation to genetics and to transmit their final resolutions to the next congress.

In connexion with the Congress, a meeting of mouse geneticists was held on August 24 to consider a set of nomenclature rules drawn up by a recently formed Committee on Mouse Genetics Nomenclature and to discuss details of a Mouse Genetics News Service. The director and staff of the. Roscoe B. Jackson Memorial Laboratory in Bar Harbor, Maine, U.S.A., have offered facilities for the publication in mimeographed form of the Mouse Genetics News. It was suggested that a register of stocks and the various pure lines should be drawn up; this should end the confusion in the naming of pure lines used in various laboratories which has arisen during the last few years. Stock lists of all the laboratories concerned should be published from time to time. It was further suggested that notice should be given by a laboratory before any stocks are discontinued ; it has happened several times in the past that valuable material has been irretrievably lost, because every laboratory has relied on other places for its maintenance. The News Service should also arrange for exchange of stocks, and it is hoped that its activities may be extended to rabbits and other rodents. The meeting also discussed the establishment of centres, preferably in the United States, for the maintenance and safe keeping of stocks, particularly of genes (pathological and otherwise) which are not purposely kept by the fancy. It was urged that this matter should receive the immediate consideration of the News Service, and that an appeal should be made to the Carnegie and Rockefeller Foundations for financial assistance.
F. A. E. Crew.

\title{
MEASUREMENT IN PSYCHOLOGY*
}

\author{
By R. J. Bartlett
}

$\mathrm{I}^{\mathrm{N}}$ the opening paragraph of "Psychology Down the Ages", Prof. C. Spearman concludes a list of difficulties facing any who seek to define psychology, with the questions: "Do the data at its disposal include what can properly be called 'measurements' ? Is it, or can it ever hope to be, or should it as much as try to be, a systematic science at all?" Dr. William Brown, in the realm of medical psychology, answers the first question in the negative. Forced into metaphysics, he writes: "Determinism, although a postulate for psychology, cannot be accepted as anything proved. In physical science there is empirical proof of it to a certain extent through measurement. By measurement we can prove to a certain extent, within certain limits of crror, the conservation of mass, the conservation of energy. . . . But there is no measurement of that sort possible in psychology. . . . The observations of psychology are primarily qualitative, not quantitative." But the writer of "Essentials of Mental Measurement" could not leave it there. He added a footnote: "But mental measurement, in a derived form, is possible in the domain of mental tests and of the psycho-physical methods."

The conflict between philosophy and experimental psychology, thus exemplified, is of long standing. Malebranche argued that mental states could be distinguished qualitatively, but not

* From the presidential address to Section J (Psychology) of the British Association, delivered in Dundee on September 1. quantitatively. Leibniz declared that mathematical treatment was impossible in psychology as it lacked continuous magnitudes. Kant said that psychology possessed no mathematical magnitudes for the reason that, "whereas the phenomena of matter possess two variables, space and time, those of mind have only the single one, time". For these and many later philosophers psychology possesses neither measurable phenomenon nor the means to measure. Still worse! Some physicists seem to have reached the same conclusion. For them measurement is impossible in psychology.

Notwithstanding criticism from philosophy and physics, the word measurement is deeply imbedded in the literature of psychology, and of late years its use has been greatly on the increase. Experimental psychology is little more than fifty years old. Galton's "Inquiries into Human Faculty" appeared in 1883 , Wundt went to Leipzig in 1875 , Weber died in 1878 and Fechner in 1887. Since then an ever-growing body of workers has been applying experimental method to psychological problems and developing its own methods of measurement and mathematical treatment of data obtained. Contemplating this work against the declaration that measurement is impossible in psychology, Prof. Spearman comments : "But the path of science is paved with achievements of the allegedly unachievable. And in point of fact, mathematical treatment is perhaps just the region where psychology has made its steadiest 